\title{
Development of a neurology training program in Haiti
}

Kerling Israel, MD, MPH, Sumita M. Strander, AB, Sosthene Pierre, MD, Louine Martineau, MD, Michelle E. Morse, MD, MPH, and Aaron L. Berkowitz, MD, PhD

Neurology ${ }^{\circledR}$ 2019;92:391-394. doi:10.1212/WNL.0000000000006960

\author{
Correspondence \\ Dr. Berkowitz \\ aberkowitz3@ \\ bwh.harvard.edu
}

From 2004 to 2015, the average number of neurologists in high-income countries increased from 3 to 5.14 per 100,000 population; the number of neurologists in low-income countries (LICs) remained static at 0.03 per $100,000 .^{1,2}$ This disparity is likely due in large part to the paucity of neurology training programs in LICs, ${ }^{3}$ leading physicians interested in neurology to train abroad, where many stay (the brain drain phenomenon). ${ }^{4}$ Neurologic disorders are the leading cause of disability-adjusted life-years and the second leading cause of mortality worldwide, ${ }^{5}$ requiring expansion of the global neurology workforce. Here we describe the development of the first neurology training program in Haiti (an LIC), supported by a visiting faculty model.

There is only one neurologist in Haiti (population $\sim 11$ million), limiting access to neurologic care for patients and neurology education for providers. Hôpital Universitaire de Mirebalais (HUM) is a 300-bed public academic hospital in Haiti, run through a partnership among the Haitian Ministry of Health, the nongovernmental organization Partners In Health (PIH), and PIH's Haitian sister organization Zanmi Lasante (ZL). HUM has residency programs in internal medicine, pediatrics, obstetrics/gynecology, surgery, and emergency medicine; a primary catchment area of $\sim 185,000$; a tertiary catchment area of $\sim 3$ million; and daily outpatient volume of $\sim 700$ patients.

\section{Program establishment}

Prior to the development of the neurology training program, we established a neurology rotation for HUM internal medicine residents. ${ }^{\text {e1 }}$ The rotation demonstrated sufficient volume and variety of neurologic patients and the efficacy of a visiting faculty model to train local providers. The Director of Graduate Medical Education (GME) at HUM (K.I.), the Deputy Chief Medical Officer for PIH in Haiti (M.E.M.), and the visiting neurologist who ran the rotation (A.L.B.) developed a proposal for a neurology fellowship program.

Since HUM is the first public tertiary hospital in Haiti managed through a public-private partnership, an Academic Directorate was created to ensure that HUM training programs align with national GME priorities. The directorate includes representatives from the Haitian Ministry of Health, the Haitian National Medical School (Faculté de Médecine et de Pharmacie de l'Université de l'Etat de Haiti [FMP]), and the leadership of ZL, PIH, and HUM. The development and approval of the program by the Academic Directorate took approximately 1 year (figure).

\section{Structure and staffing}

Each year, one trainee enters the 2-year fellowship, which includes outpatient clinic and inpatient consultation at HUM, an observership at Brigham and Women's Hospital, an academic project, a week-long neurology continuing medical education course at Harvard Medical School, and attending the American Academy of Neurology (AAN) annual meeting.

\footnotetext{
From Partners in Health/Zanmi Lasante (K.I., L.M., M.E.M., A.L.B.), Hôpital Universitaire de Mirebalais, Haiti; Dartmouth College (S.M.S.), Hanover, NH; Faculté de Médecine et de Pharmacie de I'Universite d'Etat d'Haiti (S.P.), Port-au-Prince, Haiti; and Division of Global Health Equity, Department of Medicine (M.E.M.), and Department of Neurology (A.L.B.), Brigham and Women's Hospital, Harvard Medical School, Boston, MA.

Go to Neurology.org/N for full disclosures. Funding information and disclosures deemed relevant by the authors, if any, are provided at the end of the article.
} 


\section{Glossary}

AAN = American Academy of Neurology; FMP = Faculté de Médecine et de Pharmacie de l'Université de l'Etat de Haiti; GME = Graduate Medical Education; HUM = Hôpital Universitaire de Mirebalais; PIH = Partners In Health; ZL = Zanmi Lasante.

Visiting neurology faculty were recruited through personal contacts of the program director (A.L.B.) and colleagues of these contacts. Although a 2-week-per-year minimum commitment was recommended, we allowed 1-week visits to maximize coverage. As the number of faculty increased, an undergraduate volunteer became the logistics coordinator to assist in managing faculty travel (S.M.S.).

Visiting faculty precept outpatient and inpatient consultations, provide didactics, and mentor trainees in developing research projects and teaching presentations (e.g., lectures to faculty and trainees in other departments, local internal medicine residents rotating on neurology, and in the second year, training of the first-year trainee). Teleconferences were held during weeks when no faculty were present.

Visiting faculty evaluate fellows using the Accreditation Council for Graduate Medical Education milestones. ${ }^{\mathrm{e} 2}$ The program director discusses evaluations quarterly with each fellow.

The program is funded through the HUM/PIH/ZL education budget and a private donor. Visiting faculty fund their own flights, but local ground transport, room, and board are covered by HUM/PIH/ZL (table).

The program is advertised through fliers at FMP, HUM, and newspaper/radio announcements. Applicants must have completed a residency in internal medicine or family medicine, take a 50-question entrance examination, and interview with HUM/ZL/PIH and FMP leadership. One candidate is selected each year.

Graduates receive a certificate of completion from FMP and HUM.

\section{Early experiences}

Five United States-based neurologist visiting faculty spent between 1 and 12 weeks each in Haiti during the program's first year, covering 29 weeks over 15 trips. Eleven visiting faculty covered 32 weeks over 18 trips in the second year. All but 3 faculty have made at least one return trip.

Our first trainee saw an average of 870 patients per year over his 2 years in training; lectured to local internists, internal medicine residents, and psychologists on diagnosis and management of neurologic disease; and reported a series of Zika-associated Guillain-Barré cases in Haiti that was published in Neurology ${ }^{\circledR \mathrm{e} 3}$ and presented as a platform presentation at the 2016 AAN annual meeting (receiving an AAN International Scholarship). After graduation, he has been hired as a program director in training under the mentorship of visiting faculty. Future graduates will be encouraged to work in other regions of Haiti to increase neurology capacity throughout the country.

\section{Challenges}

As the first neurology training program in Haiti, we faced several challenges.

\section{Visiting faculty model}

Although the large number of visiting faculty provides diversity of clinical teachers for the trainees, we lack continuous on-the-ground day-to-day clinical and managerial coverage. We use teleconferencing to discuss cases and hold teaching conferences when no faculty are present; this is of course no substitute for on-site precepting and clinical teaching. Most faculty only teach 1 week per year, and reliance on self-funded volunteer faculty has led to some yearly turnover, requiring substantial time investment in logistics and faculty prebriefing/

Figure Timeline in development of neurology training program

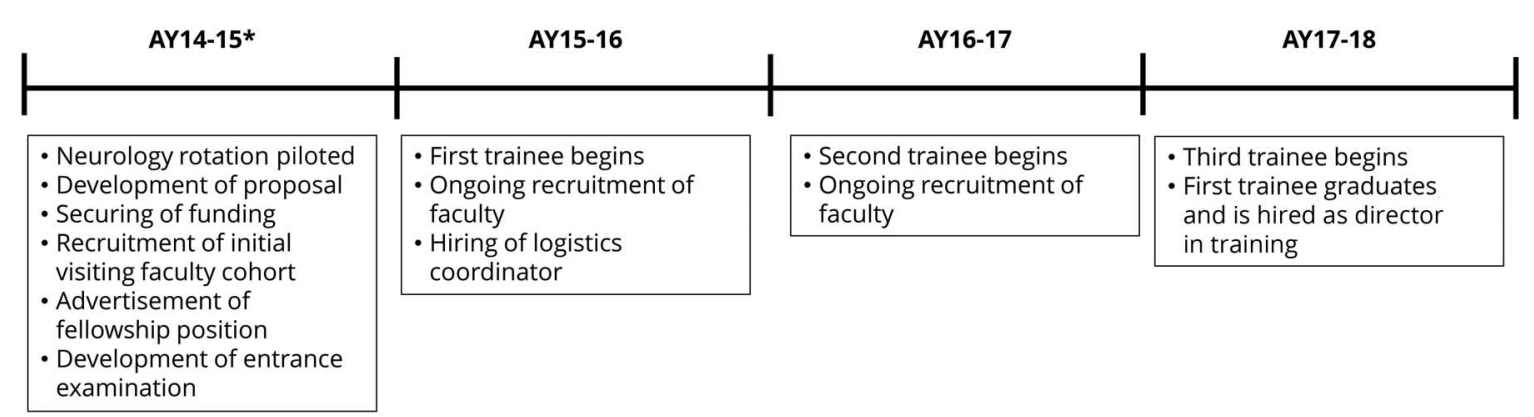

*AY14-15 = academic year 2014-2015; AY15-16 = academic year 2015-2016; AY16-17 = academic year 2016-2017; AY17-18 = academic year 2017-2018. 
Table Key steps in development of neurology training program

Preceding long-term partnership between host site and visiting neurologist

Discussion between local stakeholders and visiting neurologist

Allotment of clinic and office space for program fellows

Securing and allocation of funding for program

Arranging room and board for visiting faculty

Recruitment of visiting faculty

Recruitment and training of logistics coordinator

Development and advertisement of program application process for trainees

Creation and implementation of mechanism for bidirectional feedback

debriefing. With our first graduate serving as program director in training, we hope to transition the program to complete local leadership and independence within 5 years, alleviating some of the challenges of the visiting faculty model.

\section{Locally available neurodiagnostics}

HUM does not have EEG, EMG, or MRI. Although these tests are available in the private sector, cost prohibits the vast majority of patients from obtaining them. Our program provides didactic instruction about these modalities, but lacks practical training. Since neurodiagnostic tests are inaccessible/unaffordable to most patients in LICs, ${ }^{\text {e4 }}$ training should reflect local context. However, our trainees do gain some exposure to these modalities in their Boston rotation and through courses at the AAN, and we hope to train one of our graduates abroad in electrophysiology in the future.

\section{Recruitment}

There have only been 2 applicants per year to the program. This may be due to the fact that this is a new program in a relatively unfamiliar specialty. In addition, since general practitioners in Haiti do not require residency training to practice as physicians, pursuit of internal medicine and family medicine are considered specialties, which may de-incentivize further postgraduate training.

\section{Strengths}

Despite these challenges, the program has several strengths. It was developed at a teaching hospital with several existing GME programs, some involving visiting faculty collaboration. The program benefits from a long-term collaboration between a visiting neurologist with several years of experience in Haiti and the local hospital and its educational leadership prior to the launch of the fellowship. HUM has Haiti's only publicly accessible CT, which is not only crucial for patient care but strengthens neuroanatomy and localization training, providing the opportunity for trainees to evaluate clinical impressions. Although many graduates will likely practice in areas of Haiti without CT, clinical-radiologic correlation during training supports development of neurologic clinical reasoning.

\section{Discussion}

We report the development of a neurology training program in Haiti using a visiting faculty model. This model presents unique challenges compared to programs where there is an existing cohort of local neurologists ${ }^{\mathrm{e} 5, \mathrm{e} 6}$ or where the goal is increasing proficiency in neurologic diagnosis in nonneurologists rather than training specialists. ${ }^{\mathrm{e}, \mathrm{e} 6} \mathrm{We}$ hope that our experience can inform other efforts to develop neurology and other specialty training programs in settings where they currently do not exist.

\section{Study funding}

No targeted funding reported.

\section{Disclosure}

K. Israel, S. Strander, S. Pierre, L. Martineau, and M. Morse report no disclosures relevant to the manuscript. A. Berkowitz receives textbook royalties from Clinical Neurology and Neuroanatomy: A Localization-Based Approach (McGraw-Hill), Clinical Pathophysiology Made Ridiculously Simple (Medmaster, Inc.), and The Improvising Mind (Oxford University Press). Go to Neurology.org/N for full disclosures.

Appendix Authors

\begin{tabular}{llll}
\hline Name & Location & Role & Contribution \\
\hline Kerling & Hôpital Universitaire & Author & Collaborator in \\
Israel, MD, & de Mirebalais, & & $\begin{array}{l}\text { developing program } \\
\text { MPH }\end{array}$ \\
& Partners in Health/ & & $\begin{array}{l}\text { and in drafting, } \\
\text { Zanmi Lasante, }\end{array}$ \\
& Mirebalais, Haiti & & editing, and finalizing \\
& & manuscript \\
\hline
\end{tabular}

\begin{tabular}{|c|c|c|c|}
\hline $\begin{array}{l}\text { Sumita M } \\
\text { Strander, } \\
\text { AB }\end{array}$ & $\begin{array}{l}\text { Dartmouth College, } \\
\text { Hanover, } \mathrm{NH}\end{array}$ & Author & $\begin{array}{l}\text { Collaborator in } \\
\text { running program and } \\
\text { in drafting, editing, } \\
\text { and finalizing } \\
\text { manuscript }\end{array}$ \\
\hline $\begin{array}{l}\text { Sosthene } \\
\text { Pierre, MD }\end{array}$ & $\begin{array}{l}\text { Faculté de Médecine } \\
\text { et de Pharmacie de } \\
\text { I'Universite d'Etat } \\
\text { d'Haiti, Port-au- } \\
\text { Prince, Haiti }\end{array}$ & Author & $\begin{array}{l}\text { Collaborator in } \\
\text { developing program } \\
\text { and in editing and } \\
\text { finalizing manuscript }\end{array}$ \\
\hline $\begin{array}{l}\text { Louine } \\
\text { Martineau, } \\
\text { MD }\end{array}$ & $\begin{array}{l}\text { Hôpital Universitaire } \\
\text { de Mirebalais, } \\
\text { Partners in Health/ } \\
\text { Zanmi Lasante, } \\
\text { Mirebalais, Haiti }\end{array}$ & Author & $\begin{array}{l}\text { Collaborator in } \\
\text { developing program } \\
\text { and in editing and } \\
\text { finalizing manuscript }\end{array}$ \\
\hline $\begin{array}{l}\text { Michelle E. } \\
\text { Morse, MD, } \\
\text { MPH }\end{array}$ & $\begin{array}{l}\text { Division of Global } \\
\text { Health Equity, } \\
\text { Department of } \\
\text { Medicine, Brigham } \\
\text { and Women's } \\
\text { Hospital, Harvard } \\
\text { Medical School, } \\
\text { Boston, MA }\end{array}$ & Author & $\begin{array}{l}\text { Collaborator in } \\
\text { developing program } \\
\text { and in editing and } \\
\text { finalizing manuscript }\end{array}$ \\
\hline $\begin{array}{l}\text { Aaron L } \\
\text { Berkowitz, } \\
\text { MD, PhD }\end{array}$ & $\begin{array}{l}\text { Department of } \\
\text { Neurology, Brigham } \\
\text { and Women's } \\
\text { Hospital, Harvard } \\
\text { Medical School, } \\
\text { Boston, MA }\end{array}$ & Author & $\begin{array}{l}\text { Collaborator in } \\
\text { developing program } \\
\text { and in drafting, } \\
\text { editing, and finalizing } \\
\text { manuscript }\end{array}$ \\
\hline
\end{tabular}




\section{References}

1. WHO and World Federation of Neurology. Atlas: Country Resources for Neurological Disorders 2004. Geneva: WHO; 2004.

2. WHO and World Federation of Neurology. Atlas: Country Resources for Neurological Disorders, Second Edition. Geneva: WHO; 2017.

3. Hillis JM, Berkowitz AL. Neurology training worldwide. Semin Neurol 2018;38:135-144.
4. Dodani S, LaPorte RE. Brain drain from developing countries: how can brain drain be converted into wisdom gain? J R Soc Med 2018;98:487-491.

5. GBD 2015 Neurological Disorders Collaborator Group. Global, regional, and national burden of neurological disorders during 1990-2015: a systematic analysis for the Global Burden of Disease Study 2015. Lancet Neurol 2017;16:877-897.

References e1-e6 are available at links.lww.com/WNL/A816.

\section{Did You Know...}

... you can browse by subspecialty topics on Neurology.org?

Go to: Neurology.org and click on "Topics" in the top navigation bar.

\section{Disputes \& Debates: Rapid online correspondence}

The editors encourage comments on recent articles through Disputes \& Debates:

Access an article at Neurology.org/ $N$ and click on "COMMENT" beneath the article header. Responses will be posted within 3 business days.

Before submitting a comment to Disputes \& Debates, remember the following:

- Disputes \& Debates is restricted to comments about studies published in Neurology within the last eight weeks

- Read previously posted comments; redundant comments will not be posted

- Your submission must be 200 words or less and have a maximum of five references; reference one must be the article on which you are commenting

- You can include a maximum of five authors (including yourself)

\section{Apply for the 2019 Palatucci Advocacy Leadership Program}

The $17^{\text {th }}$ annual Palatucci Advocacy Leadership Forum will place July 18-21, 2019, at the Rancho Bernardo Inn near San Diego, CA. Apply now for this award-winning program to receive training in the areas of grassroots advocacy, leadership, relationship building, and media skills to help you mold your passionate ideas and issues into strategic action plans. The Palatucci Advocacy Leadership Forum will teach you how to:

- Turn your needs and those of your patients into action plans

- Develop media communication skills, whether in front of the camera or through written editorials

- Build and maintain relationships with reporters

- Represent your patients and profession with state and federal representatives

Learn more and apply by the March 4 deadline at AAN.com/view/PALF. 


\section{Neurology}

\section{Development of a neurology training program in Haiti}

Kerling Israel, Sumita M. Strander, Sosthene Pierre, et al. Neurology 2019;92;391-394

DOI 10.1212/WNL.0000000000006960

\section{This information is current as of February 18, 2019}

\section{Updated Information \&} Services

\section{References}

Subspecialty Collections

\section{Permissions \& Licensing}

\section{Reprints}

including high resolution figures, can be found at: http://n.neurology.org/content/92/8/391.full

This article cites 3 articles, 0 of which you can access for free at: http://n.neurology.org/content/92/8/391.full\#ref-list-1

This article, along with others on similar topics, appears in the following collection(s):

All Education

http://n.neurology.org/cgi/collection/all_education All global neurology

http://n.neurology.org/cgi/collection/all_global_neurology

Methods of education

http://n.neurology.org/cgi/collection/methods_of_education

Training-international

http://n.neurology.org/cgi/collection/training_international

Underserved populations

http://n.neurology.org/cgi/collection/underserved_populations

Information about reproducing this article in parts (figures,tables) or in its entirety can be found online at:

http://www.neurology.org/about/about_the_journal\#permissions

Information about ordering reprints can be found online:

http://n.neurology.org/subscribers/advertise

Neurology ${ }^{\circledR}$ is the official journal of the American Academy of Neurology. Published continuously since 1951, it is now a weekly with 48 issues per year. Copyright () 2019 American Academy of Neurology. All rights reserved. Print ISSN: 0028-3878. Online ISSN: 1526-632X.

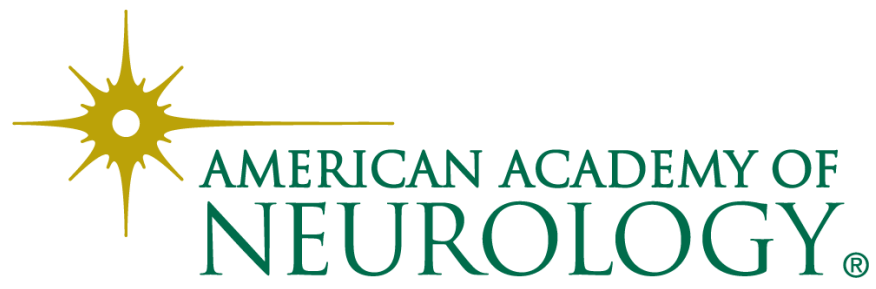

